\title{
IMPLEMENTASI SAK SYARIAH DALAM LAPORAN KEUANGAN KOPERASI PENGKREDITAN RAKYAT SYARIAH (KPRS)
}

\author{
Ni'matul Ula', Nawirah $^{2}$ \\ Universitas Islam Negeri Maulana Malik Ibrahim Malang12 \\ Jalan Gajayana No. 50 Malang, 65144, Indonesia \\ e-mail: nimatulula8@gmail.com ${ }^{1}$
}

\begin{abstract}
The purpose of this study is to determine the suitability of the presentation of the An-Nahl Pandaan KPRS financial statements to Syaria FAS. This research uses descriptive qualitative research in which the purpose is to describe and illustrate the application of Sharia Financial Accounting Standards in terms of the financial statements prepared by KPRS An-Nahl Pandaan. The techniques used in data collection are through observation, interviews, documentation, and online data search techniques. The results of the analysis and discussion of this study indicate that most of the financial statement presentations in KPRS An-Nahl are in accordance with Sharia FAS even though only the entity only reports the financial position (Balance Sheet). From the An-Nahl KPRS financial report that looks very prominent the discrepancy is that An-Nahl KPRS does not make the six other financial report components listed in the Sharia FAS because the KPRS An-Nahl management itself does not yet understand how to prepare financial reports in accordance with applicable standards.
\end{abstract}

Keywords: Islamic Financial Accounting Standards, Financial Reports; Islamic Cooperatives

\section{Abstrak}

Tujuan dari penelitian ini adalah mengetahui kesesuaian penyajian laporan keuangan KPRS An-Nahl Pandaan terhadap SAK Syariah. Penelitian ini menggunakan jenis penelitian deskriptif kualitatif dimana tujuannya adalah untuk mendeskripsikan dan menggambarkan mengenai penerapan Standar Akuntansi Keuangan Syariah yang ditinjau dari laporan keuangan yang telah dibuat oleh KPRS An-Nahl Pandaan. Teknik yang digunakan dalam pengumpulan data yaitu melalui observasi, wawancara, dokumentasi, dan teknik penelusuran data online. Hasil dari analisis dan pembahasan penelitian ini menunjukkan bahwa sebagian besar penyajian laporan keuangan di KPRS An-Nahl telah sesuai dengan SAK Syariah walaupun hanya entitas hanya membuat laporan posisi keuangan (Neraca). Dari laporan keuangan KPRS An-Nahl yang terlihat sangat menonjol ketidaksesuaiannya adalah KPRS An-Nahl tidak membuat enam komponen laporan keuangan lainnya yang tercantum dalam SAK Syariah dikarenakan pengurus KPRS An-Nahl sendiri belum memahami cara menyusun laporan keuangan yang sesuai dengan standar yang berlaku.

Kata Kunci : Standar Akuntansi Keuangan Syariah, Laporan Keuangan; Koperasi Syariah

\section{PENDAHULUAN}

Penelitian ini dilakukan dengan merujuk pada beberapa penelitian terdahulu, dengan hasil bahwa masih banyak BMT atau lembaga keuangan syariah masih lemah dalam menyusun laporan keuangan yang baik dan benar sesuai dengan SAK Syariah. Hal ini bisa dilihat dari beberapa penelitian terdahulu diantaranya yang dilakukan oleh Muhammad Rifai Habibi Ma'ruf tahun (2018) Pada KSPPS Sarana Aneka Jasa Klaten), Saiful dan Rahim (2019) pada BMT Insan Sakinah KPC Lombe Sulawesi Tenggara, Dari hasil penelitian yang ada belum sepenuhnya melakukan penyusunan laporan keuangannya sesuai SAK Syariah. Sedangkan penelitian yang dilakukan pada salah satu Bank Umum Syariah penelitian yang dilakukan oleh Mujianto dan Febriana (2018) 
Ni'matul Ula dan Nawirah : Implementasi Sak Syariah Dalam Laporan Keuangan Koperasi Pengkreditan Rakyat Syariah (Kprs)

dengan mengambil objek PTBank BCA Syariah mendapatkan hasil bahwa pelaporan laporan keuangannya sudah sesuai dengan SAK Syariah yang berlaku.

Beberapa penelitian yang dilakukan oleh peneliti sebelumnya hanya berfokus pada satu standar saja dari semua standar yang terkandung dalam SAK Syariah atau sebuah teori. Dari sebagian objek yang diteliti sebenarnya sudah mengetahui apakah standar yang harus digunakan meskipun tidak diterapkan sepenuhnya dalam penyusunan laporan keuangannya tetapi dalam transaksi sehari-hari sudah menggunakan akad yang sesuai dengan produk yang dimiliki. Objek yang sudah memahami dan menerapkan standar akuntansi yang berlaku biasanya objek yang seperti perbankan syariah karena laporan keuangannya selalu diaudit setiap tahunnya jadi sudah disesuaikan dalam penyusunan laporan keuangannya.

Warno (2014) menyatakan "koperasi yang dalam aktivitasnya menggunakan prinsip syariah maka laporan keuangan menggunakan SAK Syariah". Suatu entitas yang harus menggunakan standar tersebut adalah entitas yang melaksanakan transaksi syariah sebagai kegiatan usaha berdasarkan prinsip-prinsip syariah yang dinyatakan dalam anggaran dasarnya (IAI, 2007) .

Penelitian ini mengambil objek pada Koperasi Pengkreditan Rakyat Syariah tepatnya (KPRS)An-Nahl Pandaan. Motivasi penelitian ini adalah KPRS An-Nahl merupakan salah satu lembaga keuangan yang berbentuk koperasi syariah, bergerak dibidang usaha simpan pinjam. Koperasi ini memiliki dua produk yang digunakan dalam usahanya yaitu simpanan sesuai akad Mudharabah, dibagi menjadi dua yaitu simpanan biasa (tabungan mudharabah) dan simpanan berjangka (deposite mudharabah) serta terdapat juga pembiayaan sesuai akad Murabahah. Penelitian ini peneliti menggunakan 3 (tiga) PSAK dalam SAK Syariah yaitu PSAK 101 tentang penyajian laporan keuangan syariah, PSAK 102 tentang akuntansi murabahah dan PSAK 105 tentang akuntansi mudharabah. Dengan 3 (tiga) standar yang dipakai peneliti, penelitian ini berbeda dengan penelitian terdahulu yaitu menggunakan lebih dari satu standar dalam penerapannya.

Tujuan Penelitian ini untuk menganalis penyusunan laporan keuangan sesuai SAK Syariah serta melihat lemah tidaknya Sumber Daya Manusia yang memahami SAK Syariah dalam menyusun laporan keuangan. Implikasi dari penelitian ini agar kedepannya KPRS An-Nahl dapat menerapkan laporan keuangan yang sesuai dengan SAK Syariah. Sehingga KPRS An-Nahl dapat mengelola dana anggota secara optimal, efisien dan sesuai sasaran yang ingin dicapai.

\section{KAJIAN PUSTAKA}

Koperasi syariah merupakan badan usaha koperasi yang menjalankan usahausahanya dengan prinsip syariah islam yaitu al-quran dan assunnah. Secara teknis koperasi syariah bisa dibilang sebagai koperasi yang prinsip anggota dan kegiatannya berdasarkan prinsip-prinsip syariah islam (www.kementriankoperasi.com).

Keiso (2016) menyatakan pengertian akuntansi adalah :"Accounting consist of the three basic activities-it identifies, records, and communicates the economic events of an organization to interest users. A company identifies the economic events relevant to its business and then records those events in order to provide a history of financial activities. Recording 
Ni'matul Ula dan Nawirah : Implementasi Sak Syariah Dalam Laporan Keuangan Koperasi Pengkreditan Rakyat Syariah (Kprs)

consists of keeping a systematic, chronological diary of events, measured in dollar and cents. Finally, communicates the collected information to interest user by means accounting reports are called financial statement".

Laporan keuangan merupakan catatan informasi keuangan suatu organisasi atau perusahaan pada suatu periode akuntansi yang dapat digunakan untuk menggambarkan kinerja organisasi atau perusahaan tersebut. Laporan keuangan merupakan sarana untuk pengomunikasikan informasi keuangan utama kepada pihak dari luar perusahaan. Laporan yang sering disajikan seperti laporan posisi keuangan, laporan laba rugi, laporan arus kas, dan laporan perubahan modal. Catatan Atas Laporan Keuangan merupakan bagian itegral dari setiap laporan keuangan (Kieso, 2014).

Standar Akuntansi Syariah (SAS) adalah Pernyataan Standar Akuntansi Keuangan (PSAK) Syariah yang ditujukan untuk entitas yang melakukan transaksi syariah baik entitas lembaga syariah maupun lembaga non syariah. SAK Syariah menjelaskan bahwa terdapat 11 (sebelas) Penyataan standar Akuntansi Keuangan (PSAK) yang terkadung didalamnya yaitu PSAK 101 tentang Penyajian Laporan Keuangan Syariah, PSAK 102 tentang Akuntansi Murabahah, PSAK 103 tentang Akuntansi Sala, PSAK 104 tentang Akuntansi Istishna, PSAK 105 tentang Akuntansi Mudharabah, PSAK 106 tentang Akuntansi Musyarakah, PSAK 107 tentang Akuntansi Ijarah, PSAK 108 tentang Akuntansi Transaksi Akuntansi Syariah, PSAK 109 tentang Akuntansi Zakat dan infak / sedekah, PSAK 110 tentang Akuntansi Sukuk, PSAK 111 Akuntansi W'ad.

\section{PSAK 101 Tentang Penyajian Laporan Keuangan}

PSAK 101 dikeluarkan oleh Dewan Standar Akuntansi Keuangan Ikatan Akuntan Indonesia (DSAK IAI). PSAK ini menggantikan ketentuan terkait penyajian laporan keuangan syariah yang tertuang dalam PSAK 59: Akuntansi Perbankan Syariah. IAI (2007) menyatakan Laporan Keuangan yang disajikan pada entitas syariah yang sesuai dengan PSAK 101 terdiri dari tujuh komponen yaitu, laporan posisi keuangan, laporan laba rugi, laporan perubahan ekuitas, laporan arus kas, laporan sumber dan penggunaan dana zakat, laporan sumber dan penggunaan dana kebajikan, catatan atas laporan keuangan.

\section{PSAK 102 Tentang Akuntansi Murabahah}

Murabahah adalah akad jual beli barang dengan harga jual sebesar biaya perolehan ditambah keuntungan yang disepakati dan penjual harus mengungkapkan biaya perolehan barang tersebut kepada pembeli (IAI ,2007). Wiroso (2011) menyatakan, murabahah (bai' murabahah) merupakan jual beli barang pada harga asal dengan tambahan keuntungan yang disepakati. Akad bai' murabahah, dimana penjual harus memberitahu harga produk yang ia beli dan menentukan suatu tingkat keuntungan sebagai tambahannya. Rukun akad murabahah yang harus ada pada saat akan melakukan transaksi yakni, ba'i, musytari, tsaman dan ijab qabul.

\section{PSAK 105 Tentang Akuntansi Mudharabah}

Mudharabah merupakan risky business, akad kerjasama usaha antara pihak shabib al-mal dengan dimana keuntungan dibagi sesuai nisbah yang disepakati, sedangkan kerugian ditanggung pemilik dana. Rukun akad mudharabah yaitu, orang yang berakad, modal, usaha, keuntungan dan ijab qabul (Wiroso, 2011).

IAI (2007) mengemukakan Mudharabah adalah akad ,kerjasama usaha antara dua pihak, dimana shabib al-mal menyediakan seluruh dana, sedangkan mudharib 
Ni'matul Ula dan Nawirah : Implementasi Sak Syariah Dalam Laporan Keuangan Koperasi Pengkreditan Rakyat Syariah (Kprs)

bertindak selaku pengelola, keuntungan dibagi di antara mereka sesuai kesepakatan bagian sedangkan kerugian finansial hanya ditanggung oleh pemilik dana. Terdapat 3(tiga) bagian dalam Mudharabah yakni, mudharabah muthlaqah, mudharabah muqayyadah dan mudharabah musytarakah.

\section{METODE}

Penelitian ini merupakan Penelitian dengan pendekatan kualitatif deskriptif Pendekatan deskriptif merupakan analisis data yang dilakukan dengan cara mengumpulkan data, mengelola data, kemudian menyajikan data observasi agar pihak lain dapat mudah memperoleh gambaran mengenai objek yang diteliti. Penelitian ini dimaksudkan untuk mendeskripsikan dan menggambarkan mengenai penerapan Standar Akuntansi Keuangan Syariah (SAK Syariah) yang ditinjau dari laporan keuangan yang telah dibuat oleh KPRS An-Nahl.

Penelitian ini menggunakan data primer dan data sekunder. data yang terkait dengan data primer diantaranya sejarah dari KPRS An-Nahl, struktur organisasi, visi misi dan laporan keuangan KPRS An-Nahl. Data ini diperoleh dengan cara melakukan wawancara kepada Ketua KPRS An-Nahl yaitu Ibu Hj.Ma'nusa Urfah dan Manager objek yaitu Ibu Sri Rahayu., SE. Sedangkan data sekunder diperoleh dengan cara mengumpulkan bukti-bukti transaksi, laporan keuangan yang dibuat oleh KPRS AnNahl.

\section{HASIL DAN PEMBAHASAN}

\section{Perbandingan Penyajian Laporan Keuangan Menurut SAK Syariah dengan Penyajian Laporan Keuangan Menurut KPRS An-Nahl Pandaan}

Peneliti merujuk pada SAK syariah yang merupakan standar akuntansi yang digunakan oleh oleh entitas syariah dalam menyusun dan menyajikan laporan keuangannya. Laporan keuangan yang dibuat oleh KPRS An-Nahl menggunakan standar yang berbasis syariah. Standar yang digunakan dalam penelitian ini mengacu pada PSAK 101 tentang penyajian laporan keuangan, PSAK 102 tentang Murabahah, PSAK 105 tentang Mudharabah. Laporan keuangan yang dibuat oleh KPRS An-Nahl sudah secara komputerisasi dengan menggunakan aplikasi. Berdasarkan gambaran penyajian laporan keuangan yang ada, antara laporan keuangan yang dibuat oleh KPRS An-Nahl dan laporan keuangan yang sesuai dengan SAK Syariah terdapat beberapa item yang tidak sesuai. Sehingga penulis membutuhkan alat untuk mengetahui kesesuaian antara laporan keuangan KPRS An-Nahl dengan laporan keuangan yang sesuai SAK Syariah. Dikerenakan KPRS An-Nahl hanya membuat laporan keuangan berupa laporan posisi keuangan sehingga peneliti hanya akan menjelaskan dan memaparkan tabel perbandingan laporan posisi keuangan berdasarkan SAK Syariah dan laporan keuangan yang dibuat KPRS An-Nahl.

\section{Laporan Posisi Keuangan (Neraca) Berdasarkan PSAK 101}

Laporan posisi keuangan entitas mencakup pos-pos: (1) Kas dan setara kas, (2) Aset keuangan, (3) Piutang usaha dan piutang lainnya, (4) Persediaan, (5) Investasi yang diperlukan menggunakan metode ekuitas, (6) Aset tetap, (7) Aset tak berwujud, (8) Utang usaha dan utang lainnya, (9) Utang pajak, (10) Dana syirkah temporer, (11) Hak 
Ni'matul Ula dan Nawirah : Implementasi Sak Syariah Dalam Laporan Keuangan Koperasi Pengkreditan Rakyat Syariah (Kprs)

minoritas, (12) Modal saham dan ekuitas lainnya.Berikut merupakan kerangka Laporan Posisi Keuangan SAK Syariah yang diatur dalam PSAK 101.

Tabel 1. Kerangka Laporan Posisi Keuangan Berdasarkan PSAK 101

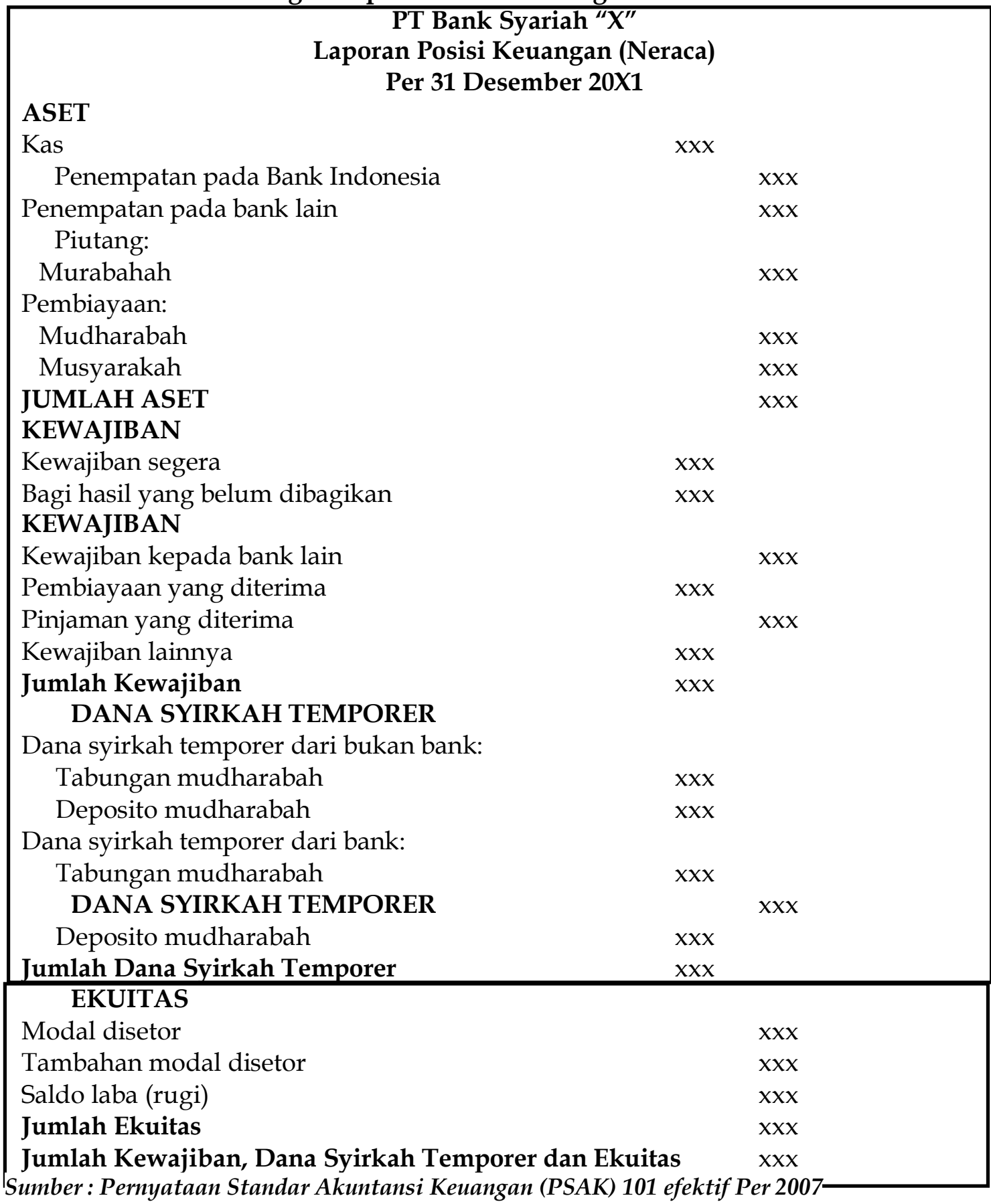

\section{Laporan Posisi Keuangan (Neraca) KPRS An-Nahl}

Laporan Neraca pada KPRS An-Nahl bulan Agustus tahun 2018 sama halnya dengan laporan posisi keuangan, dimana laporam tersebut dibuat oleh KPRS An-Nahl setiap tahun. Sedangkan akun-akun utama yang terdapat di dalam Laporan Keuangan atau Neraca KPRS An-Nahl pada sisi debit yaitu Aktiva dengan jumlah Rp. 28.189.954.501,71,-, dengan jumlah pembiayaan murabahah sebesar Rp. 22.051.369.840,69,- dan jumlah PPAP Pembiayaan sejumlah Rp. 10.000.000,-. Selain itu pada sisi kredit terdapat kewajiban dengan total kewajiban Rp 24.867.208.617,38,- dan 
Ni'matul Ula dan Nawirah : Implementasi Sak Syariah Dalam Laporan Keuangan Koperasi Pengkreditan Rakyat Syariah (Kprs)

jumlah simpanan pihak ketiga atau Mudharabah yang terbagi menjadi dua yaitu Mudharabah sebesar Rp.5.236.742.967,19,- dan Mudharabah berjangka sebesar Rp.19.510.505.000,- (Neraca KPRS An-Nahl, 2018).

Perbandingan laporan keuangan berdasarkan SAK Syariah dan laporan keuangan KPRS An-Nahl nampak pada Tabel 2 


\begin{tabular}{|c|c|c|c|}
\hline \multicolumn{4}{|c|}{ Tabel 2. Perbandingan Laporan keuangan KPRS An-Nahl dengan Laporan Keuangan SAK Syariah } \\
\hline Laporan & Item Perbandingan & SAK Syariah & Hasil Kajian \\
\hline \multirow[t]{5}{*}{$\begin{array}{c}\text { Laporan Posisi } \\
\text { Keuangan } \\
\text { (Neraca) }\end{array}$} & $\begin{array}{l}\text { Aktiva } \\
\text { Harta }\end{array}$ & Aset & $\begin{array}{l}\text { Belum sesuai dengan SAK syariah } \\
\text { dikarenakan dalam standar yang } \\
\text { berlaku seharusnya Aset. }\end{array}$ \\
\hline & $\begin{array}{l}\text { Pembiayaan Murabahah } \\
\text { Angsuran Bulanan } \\
\text { Kontrak Bulanan } \\
\text { Angsuran Mingguan } \\
\text { Kontrak Mingguan } \\
\text { Harian } \\
\end{array}$ & $\begin{array}{l}\text { Piutang } \\
\text { Murabahah } \\
\text { Salam } \\
\text { Istishna } \\
\quad \text { Ijarah }\end{array}$ & $\begin{array}{l}\text { Tidak sesuai berdasarkan SAK Syariah } \\
\text { dikarenakan Murabahah dalam laporan } \\
\text { keuangan yang berbasis syariah } \\
\text { harusnya dicatat dan diakui sebagai } \\
\text { piutang bukan pembiayaan lagi sebab } \\
\text { sudah menjadi angsuran. }\end{array}$ \\
\hline & $\begin{array}{l}\text { PPAP } \\
\quad \text { PPAP Pembiayaan }\end{array}$ & CKP & $\begin{array}{l}\text { Belum sesuai dengan SAK Syariah. } \\
\text { Dikarenakan pada akun ini seharusnya } \\
\text { yang dipakai adalah cadangan kerugian } \\
\text { akibat pembiayaan murabahah yang } \\
\text { tidak dapat dilunasi Dan nama akun } \\
\text { bukan lagi pembiayaan harusnya } \\
\text { piutang. }\end{array}$ \\
\hline & PASIVA & KEWAJIBAN/ LIABILITAS & $\begin{array}{l}\text { Belum sesuai dengan SAK Syariah } \\
\text { seharusnya akun disajikan Liabilitas. }\end{array}$ \\
\hline & $\begin{array}{l}\text { Simpanan Pihak Ketiga } \\
\text { Mudharabah } \\
\text { Mudharabah Harian } \\
\text { Mudharabah Ziarah } \\
\text { Tabungan Harian } \\
\text { Berjangka Mudharabah } \\
\text { 1 (satu) bulan } \\
3 \text { (tiga) bulan }\end{array}$ & $\begin{array}{l}\text { Simpanan } \\
\text { Simpanan dari Bank Lain } \\
\text { Dana Syirkah Temporer } \\
\text { Dari Bukan Bank: } \\
\text { Deposito Mudharabah } \\
\text { Dari BBank: } \\
\text { Deposito Mudharabah }\end{array}$ & $\begin{array}{l}\text { Pada akun simpanan pihak ketiga sudah } \\
\text { sesuai dengan SAK Syariah penyajian } \\
\text { akunnya. Tetapi pada akun yang } \\
\text { dijabarkan belum sesuai dikarenakan } \\
\text { untuk tabungan Mudharabah } \\
\text { seharusnya disajikan pada sub akun } \\
\text { dana syirkah temporer. }\end{array}$ \\
\hline
\end{tabular}

Sumber : Hasil analisis perbandingan peneliti (2019) 
Ni'matul Ula dan Nawirah : Implementasi Sak Syariah Dalam Laporan Keuangan Koperasi Pengkreditan Rakyat Syariah (Kprs)

Berdasarkan dari tabel 3 diperoleh hasil bahwasannya Pada laporan keuangan KPRS An-Nahl berdasarkan PSAK 101, 102 dan 105 masih belum sesuai dengan standar dikarenakan pada PSAK 101 berdasarkan penyajiannya koperasi masih menggunakan penyajian standar yang lama dan pada pengakuan dan pengukurannya sesuai dengan akad yang berlaku juga masih belum sesuai yang seharusnya sudah diakui dan diukur merujuk pada PSAK 102 dan PSAK 105.

\section{Pembahasan dan Analisis Akun-akun Laporan Keuangan KPRS An-Nahl Pandaan Sesuai SAK Syariah}

Hasil perbandingan laporan posisi keuangan KPRS An-Nahl dengan SAK Syariah setiap akun-akunnya sudah banyak yang sesuai dan yang belum sesuai sudah dijabarkan alasan dan seharusnya disajikan dengan akun yang benar sebagaimana mestinya. Pada analisis akun-akun ini akan membahas tentang setiap akunnya dengan analisis sesuai dengan PSAK 101 tentang penyajian laporan keuangan. Dikarenakan pada KPRS AnNahl Pandaan hanya membuat Laporan posisi keuangan sehingga akun-akun yang akan dianalisis hanya sebatas Laporan posisi keuangan. Analisis yang akan dilakukan pada akun-akun yaitu dengan melihat apakah akun-akun yang ada dalam Laporan posisi keuangan sudah sesuai.

Hasil penelitian berdasarkan (1) Pengakuan, KPRS An-Nahl sudah mengakui sesuai dengan perolehan dari transaksinya dan jumlah yang diakui juga sudah sesuai dengan yang ada pada saat transaksi berlangsung. Dana-dana investasi dan cadanganpun sudah diakui sesuai dengan jumlah yang disepakati dan ditempatkan pada akun-akun yang sudah menjadi kebijakan koperasi dalam mengakuinya. (2) Pengukuran, KPRS AnNahl dalam mengukur transaksi yang terjadi sesuai dengan jumlah yang diterima dan yang keluar sesuai dengan kebijakan perusahaan. Dana investasi dan cadanganpun diukur dengan jumlah yang sudah disepakati (3) Penyajian, Laporan posisi keuangan KPRS An-Nahl sudah disajikan sesuai dengan jumlah dan tertera pada akun-akun yang seharusnya. Namun dalam pnyajiannya masih banyak menggunakan akun-akun yang lama. (4) Pengungkapan Hal-hal yang seharusnya diungkapkan dalam Catatan Atas Laporan Keuangan (CALK) seperti rincian jumlah uang kas belum diungkapkan oleh KPRS An-Nahl dan sampai saat ini Koperasi tidak membuat CALK untuk mengungkapkan hal tersebut. Seharusnya dalam Catatan Atas Laporan Keuangan (CALK) diungkapkan jumlah yang sesuai dengan yang disajikan pada Laporan posisi keuangan.

\section{KESIMPULAN}

Penelitian ini disimpulkan bahwa akun-akun yang disajikan dalam laporan keuangan KPRS An-Nahl lebih banyak yang belum sesuai jika dibandingkan dengan yang sesuai. Masalah penyusunan dan penyajian yang ada pada laporan keuangan KPRS An-Nahl ini disebabkan karena KPRS An-Nahl hanya mengandalkan sistem aplikasi yang dimiliki tanpa tahu standar apa yang digunakan dan harus diterapkan. Selain itu KPRS An-Nahl juga tidak melihat perkembangan penyusunan dan penyajian laporan keuangan 
Ni'matul Ula dan Nawirah : Implementasi Sak Syariah Dalam Laporan Keuangan Koperasi Pengkreditan Rakyat Syariah (Kprs)

untuk penamaan setiap akun yang seharusnya diperbaiki setiap ada perbaruan untuk penamaan dalam penyajian akun pada laporan keuangan.

Kendala terjadi dalam bagian akuntan atau SDM yang bekerja dalam KPRS AnNahl mengenai pemahaman standar akuntansi yang seharusnya diterapkan serta kurangnya pengetahuan terkait perkembangan standar akuntansi. Dengan adanya kendala tersebut KPRS An-Nahl sampai saat ini belum melakukan perbaikan dalam penyusunan laporan keuangannya sehingga laporan disajikan setiap bulannya akan sama dengan tidak berdasarkan standar akuntansi yang berlaku. PSAK yang dijadikan standar dalam penelitian ini adalah SAK Syariah dan juga perbandingan yang dilakukan hanya sebatas laporan posisi keuangan, dikarenakan sesuai dengan laporan yang dimiliki KPRS An-Nahl.

\section{DAFTAR PUSTAKA}

Keiso, Donald E., Weygandt, Jerry J., and Kimmci, Paul D. 2016. Accounting Principles Twelfth Edition, Asia : John Wiley \& Sons.

Kementerian Koperasi dan Usaha Kecil dan Menengah Republik Indonesia. 2018. http:// www.depkop.go.id diakses 9 Maret 2019

Ma'ruf H.R Muhammad. 2018. Analisis Penerapan Akuntansi Syariah Pada Transaksi Pembiayaan Musyarakah Berdasarkan PSAK No. 106 (Studi Pada KSPPS Sarana Aneka Jasa Klaten). Surakarta : Fakultas Ekonomi dan Bisnis Islam Institute Agama Islam Negeri Surakarta.

Mujianto Eko, Febriana Annisa. 2018. Penerapan Akuntansi Murabahah Pada PT. Bank BCA Syariah Sesuai Dengan PSAK 102. Surabaya : Sekolah Tinggi Ilmu Ekonomi Urip Sumoharjo

PSAK 101: Penyajian Laporan Keuangan Syariah.2018. http:/ /iaiglobal.or.id/v03/standar-akuntansi-keuangan/pernyataan-sas64-psak-syariah-101 diakses 20 Maret 2019 diakses 20 Maret 2019

PSAK 102 : Akuntansi Murabahah.2018.http://iaiglobal.or.id/v03/standarakuntansi-keuangan/pernyataan-sas-65-psak-102-akuntansi-murabahah diakses 21 Maret 2019

PSAK 105 : Akuntansi Mudharabah.2018.http://iaiglobal.or.id/v03/standarakuntansi-keuangan/pernyataan-sas-68-psak-syariah-105 diakses 21 Maret 2019

Purwoko Sigit., 2017. Analisis Penerapan Akuntansi Pembiayaan Mudharabah Berdasarkan PSAK 105. Yogyakarta: Prodi Akuntansi Uninversitas Negerti Yogyakarta.

SAK Syariah. 2018. http://iaiglobal.or.id/v03/standar-akuntansi-keuangan/sas-efektif16-sak-syariah-efektif-per-1-januari-2018 diakses 20 Maret 2019 
Ni'matul Ula dan Nawirah : Implementasi Sak Syariah Dalam Laporan Keuangan Koperasi Pengkreditan Rakyat Syariah (Kprs)

Sugiyono. 2016. Metode Penelitian Kualitatif, Kuantitatif, dan $R$ dan D. Bandung : CV Alfabeta.

Warno, Setiyanti W.S., 2014. Konsistensi Penerapan SAK Syariah pada Koperasi Syariah. Semarang. Dosen Tetap STIE

Wiroso. 2011. Akuntansi Transaksi Syariah. Jakarta : Ikatan Akuntansi Indonesia 